\title{
Use of $\mathrm{NO}_{\mathrm{x}}{ }^{-}$microsensors to estimate the activity of sediment nitrification and $\mathrm{NO}_{\mathrm{x}}{ }^{-}$consumption along an estuarine salinity, nitrate, and light gradient
}

\author{
Rikke Louise Meyer*, Thomas Kjær, Niels Peter Revsbech \\ Department of Microbial Ecology, University of Aarhus, Building 540, Ny Munkegade, 8000 Aarhus C, Denmark
}

\begin{abstract}
Microprofiles of nitrate plus nitrite $\left(\mathrm{NO}_{\mathrm{x}}^{-}\right)$were measured in sediment cores sampled at 6 stations along a nitrate and salinity gradient and a depth transect in Randers Fjord, Denmark. Rates of $\mathrm{NO}_{\mathrm{x}}{ }^{-}$production and consumption were calculated from the concentration profiles to describe the variation of these processes under in situ conditions. A microscale biosensor for $\mathrm{NO}_{\mathrm{x}}{ }^{-}$was used to obtain $\mathrm{NO}_{\mathrm{x}}^{-}$profiles in darkness and under in situ light conditions. This new tool for nitrate plus nitrite measurements in saline environments made it possible to measure $\mathrm{NO}_{\mathrm{x}}{ }^{-}$profiles with submicromolar resolution and without interference from chemical species other than nitrous oxide. The $\mathrm{NO}_{\mathrm{x}}{ }^{-}$concentration in the inner and middle part of the estuary was very high (55 to $220 \mu \mathrm{M}$ ). The range of $\mathrm{NO}_{\mathrm{x}}{ }^{-}$consumption rates found here (47 to $577 \mu \mathrm{mol} \mathrm{N} \mathrm{m}{ }^{-2} \mathrm{~h}^{-1}$ ) were within the range of denitrification rates found in similar environments (measured by ${ }^{15} \mathrm{~N}$ isotope techniques). The $\mathrm{NO}_{\mathrm{x}}{ }^{-}$concentration in the water was low at the outermost part of the estuary, and all $\mathrm{NO}_{\mathrm{x}}{ }^{-}$diffusing into the sediment was consumed in the oxic zone (top $1 \mathrm{~mm}$ ) of the sediment. In this study, $\mathrm{NO}_{\mathrm{x}}{ }^{-}$consumption was not closely coupled to nitrification and depended mostly on $\mathrm{NO}_{\mathrm{x}}^{-}$(mainly nitrate) from the overlying water. The $\mathrm{NO}_{\mathrm{x}}^{-}$consumption rates were correlated with $\mathrm{NO}_{\mathrm{x}}^{-}$concentration in the overlying water, but the sediment was a sink for $\mathrm{NO}_{\mathrm{x}}{ }^{-}$only at the highest $\mathrm{NO}_{\mathrm{x}}{ }^{-}$concentrations. The effect of changing light conditions on $\mathrm{NO}_{\mathrm{x}}{ }^{-}$consumption was significant at the station with the highest $\mathrm{NO}_{\mathrm{x}}{ }^{-}$ level but not at other stations.
\end{abstract}

KEY WORDS: Nitrate biosensor $\cdot$ Nitrogen transformation Resale or republication not permitted without written consent of the publisher

\section{INTRODUCTION}

Estuaries are able to decrease the amount of inorganic nitrogen derived from land and transported by rivers to the oceans by up to $50 \%$ (Seitzinger 1988). Denitrification of nitrate and coupled nitrification/denitrification of ammonia to $\mathrm{N}_{2}$ are key processes in removing inorganic nitrogen compounds from the aquatic environment. Therefore, nitrogen transformations in estuaries have been studied intensively over the last 2 decades to achieve an understanding of the processes involved and to assess the role of estuaries in preventing eutrophication of the sea (for a review, see Seitzinger 1988 or Herbert 1999).

\footnotetext{
*E-mail: biorlm@biology.au.dk
}

Techniques used in studies of nitrogen transformations include mass balance calculations (Messer \& Brezonik 1983), flux measurements of relevant chemical species in whole core microcosms (Andersen et al. 1984, Christensen et al. 1990), tracer techniques (Rysgaard et al. 1993, Risgaard-Petersen et al. 1994), and microsensors (Nielsen et al. 1990, Jensen et al. 1993, 1994). Studies of fluxes provide overall information about exchange of inorganic nutrients over the sediment surface, and by using isotopic tracers in such studies, it is possible to obtain detailed information about the individual processes taking place within the sediment. Microsensor profiles of substrates or products of the processes of interest can visualise the localisation and net rates of the nitrogen-transforming processes and elucidate interactions with chemical and physical factors in the microenvironment. 
Studies using Liquid Ion eXchange-type (LIX) nitrate microsensors have provided detailed information about the distribution of nitrate in lake sediments and how this is affected by changes in light or oxygen conditions (De Beer \& Sweerts 1989, Jensen et al. 1993, 1994). These studies, however, are restricted to freshwater systems because the LIX sensors are susceptible to interference from other ions such as bicarbonate and chloride (Jensen et al. 1993, Verschuren et al. 1999). The $\mathrm{NO}_{\mathrm{x}}{ }^{-}$biosensor (Larsen et al. 1997) used in this study is highly sensitive, and the only interfering substance is nitrous oxide. It thus provides us with a new tool to investigate the microscale distribution of $\mathrm{NO}_{\mathrm{x}}{ }^{-}$ in marine environments.

The aim of this study is to describe variations in the microscale distribution of $\mathrm{NO}_{\mathrm{x}}{ }^{-}$and $\mathrm{NO}_{\mathrm{x}}^{-}$production/consumption at various light intensities along a gradient in water phase salinity and nitrate concentrations. We stress that the present study describes the net $\mathrm{NO}_{\mathrm{x}}{ }^{-}$production/consumption rates. A number of biological processes such as denitrification, dissimilative reduction of $\mathrm{NO}_{\mathrm{x}}^{-}$to ammonia, oxidation of ammonia with nitrite (anammox), and $\mathrm{NO}_{\mathrm{x}}{ }^{-}$assimilation may contribute to the observed $\mathrm{NO}_{\mathrm{x}}{ }^{-}$consumption, and we cannot distinguish the individual $\mathrm{NO}_{\mathrm{x}}^{-}$consuming processes.

\section{MATERIALS AND METHODS}

Sampling. Sediment cores from 6 stations along a nitrate/salinity gradient and a depth transect in Randers Fjord, Denmark (Fig. 1) were collected in June 1999. The depth transect (Stns 2 to 5) was at medium salinity. The fjord receives about 1000 million $\mathrm{m}^{3} \mathrm{yr}^{-1}$ of freshwater from 2 streams with agricultural catchment areas, and it therefore receives a large input of nitrate (Sømod et al. 1999). The fjord is very shallow (less than $2 \mathrm{~m}$ in most places) and the large input of freshwater combined with a tidal amplitude of 0.4 to $0.6 \mathrm{~m}$ results in a highly fluctuating salinity. The salinity may thus fluctuate between 4 and $21 \%$ within a few days at Stns 2 to 5 .

Temperature, oxygen concentration, and light intensity at the sediment surface were measured in situ at each station and water samples were collected to determine the salinity and the concentrations of nitrate and nitrite. Microsensor measurements were performed on 3 cores (36 mm inner diameter) from each station. In the laboratory, the sediment was pushed upward in the Plexiglas cylinder so that the sediment surface was flush with the edge of the cylinder. The cores were stored in the dark for 24 to $60 \mathrm{~h}$ at $15^{\circ} \mathrm{C}$ while immersed in constantly aerated water from the sampling site before microsensor measurements could

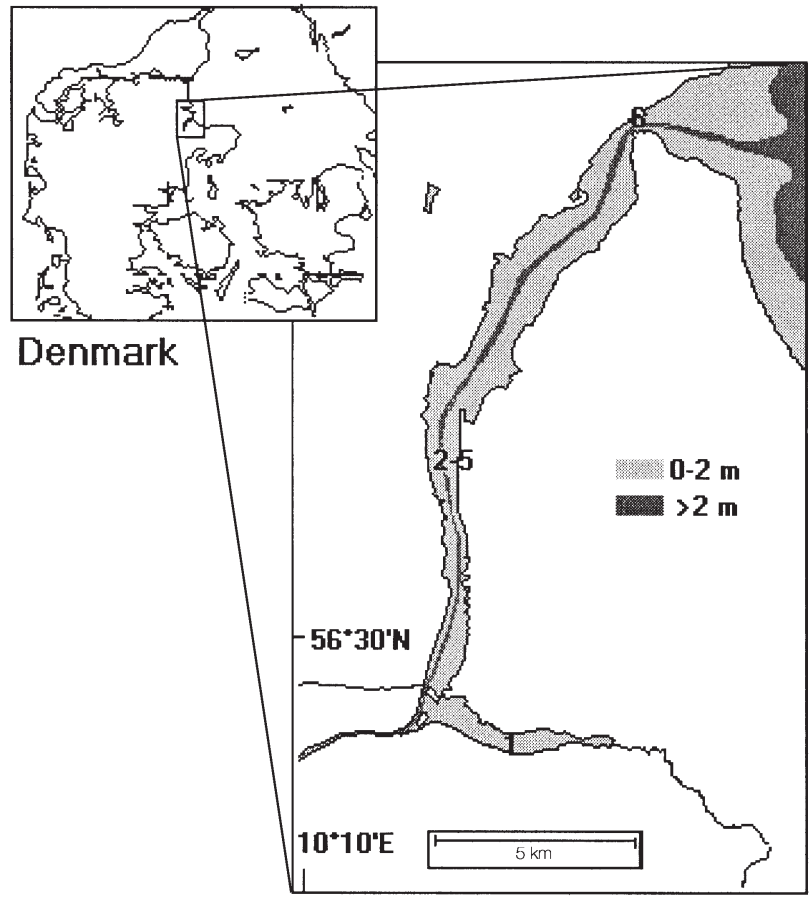

Fig. 1. Map of Randers Fjord, Denmark, showing the locations of the different sampling stations

be performed. An additional 3 cores were used for whole-core flux measurements of the oxygen uptake.

Physical and chemical analyses. In the field, light intensity was measured with a LI-192SA underwater quantum sensor (measuring light in the 400 to $700 \mathrm{~nm}$ range) attached to a LI-1000 datalogger (LI-COR, Lincoln, NE). Temperature and oxygen were both measured with a YSI oxygen meter, model 54 A (Yellow Spring Instruments, Yellow Stone, $\mathrm{OH}$ ).

Nitrate and nitrite in the water samples was determined by high-performance liquid chromatography (HPLC) (SYKAM, Gliching, Germany, anion separation column LCA A14) with $40 \mathrm{mM} \mathrm{NaCl}$ as eluent. Salinity was measured with a conductivity meter (CDM3, Radiometer, Copenhagen).

Microsensors. The oxygen sensor used was a Clarktype microsensor (Revsbech 1989a) (tip size $=12 \mu \mathrm{m}$, $90 \%$ response time $=1 \mathrm{~s},<1 \%$ stirring sensitivity). The sensor was calibrated by a 2-point calibration in $\mathrm{N}_{2}$ and air-saturated water. The $\mathrm{O}_{2}$ concentration of airsaturated water was calculated from the equation described by García \& Gordon (1992).

The nitrate/nitrite biosensor (tip size $=70 \mu \mathrm{m}, 90 \%$ response time $=45 \mathrm{~s}$, no detectable stirring sensitivity) was constructed as described in Larsen et al. (1997). The sensor is based on bacterial reduction of nitrate and nitrite to $\mathrm{N}_{2} \mathrm{O}$, which is subsequently detected by an electrochemical $\mathrm{N}_{2} \mathrm{O}$ sensor. The sensor is equally 
sensitive to nitrate and nitrite and is referred to as a $\mathrm{NO}_{\mathrm{x}}{ }^{-}$sensor. The sensor was calibrated by plotting the current against different nitrate concentrations in water of a salinity and temperature identical to the sample to be analysed. For measurements at very low nitrate concentrations, a $+0.5 \mathrm{~V}$ charge was applied across the tip membrane to electrophoretically mediate the transport of nitrate/nitrite ions into the sensor (Kjær et al. 1999). This increased the response of the sensor and made it possible to detect very low $(<1 \mu \mathrm{M})$ nitrate concentrations with high accuracy. When inverting the charge, anions were excluded from the sensor, and the only detectable substance was $\mathrm{N}_{2} \mathrm{O}$. This made it possible to investigate the interference from $\mathrm{N}_{2} \mathrm{O}$, which was undetectable in the experiments described below.

Microprofiles of oxygen and $\mathrm{NO}_{\mathrm{x}}^{-}$. The sediment cores were placed in a temperature-controlled container with water from the sampling site $\left(15^{\circ} \mathrm{C}\right)$. The water was flushed with air to ensure sufficient stirring and to keep the oxygen concentration in the water constant, as changes in oxygen concentration can affect nitrification and denitrification rates (Seitzinger 1988, Rysgaard et al. 1994, Lorenzen et al. 1998). All experiments were carried out at the light intensity, temperature, salinity, oxygen saturation, and nitrate concentrations found on the day of sampling.

The oxygen and $\mathrm{NO}_{\mathrm{x}}^{-}$sensors were mounted together on a computer-controlled micromanipulator. Profiles of oxygen and $\mathrm{NO}_{\mathrm{x}}^{-}$were measured simultaneously along the same vertical profile, with the tip of the oxygen sensor placed $0.6 \mathrm{~mm}$ in front of the $\mathrm{NO}_{\mathrm{x}}^{-}$ sensor. The tip diameter of the oxygen sensor is much smaller than the one of the $\mathrm{NO}_{\mathrm{x}}^{-}$sensor, and it therefore only causes minimal disturbance to the $\mathrm{NO}_{\mathrm{x}}{ }^{-}$profiles. However, the large size of the $\mathrm{NO}_{\mathrm{x}}{ }^{-}$sensor and the placement of the $\mathrm{O}_{2}$ sensor in front of it likely affect the $\mathrm{NO}_{\mathrm{x}}{ }^{-}$profile in the diffusive boundary layer above the sediment surface. It is known that even sensors smaller than $10 \mu \mathrm{m}$ in tip diameter can cause a depression of the diffusive boundary layer (Glud et al. 1994). The profiles were obtained by measuring at 2 to 3 random spots in at least 2 different cores from the same station.

The light intensity for profiles measured during illumination was adapted to match the in situ intensity. The light intensity measured at the water surface on the day of sampling was $500 \mu \mathrm{E}$ (100\% cloud cover), and the light intensities at the sediment surface of Stns $1,2,3$, and 6 were $80,320,200$, and $85 \mu$ E. When shifting between measurements of dark profiles to light profiles in the same core, the cores were incubated at the given light intensity overnight to ensure that gradients of oxygen and $\mathrm{NO}_{\mathrm{x}}^{-}$in the sediment approached an equilibrium.
Profile interpretation. Net metabolic rates of $\mathrm{NO}_{\mathrm{x}}^{-}$ production and consumption were calculated from the curvature of the concentration profiles. Fick's first law of diffusion (Crank 1983) is:

$$
J=-\varphi \cdot D_{\mathrm{s}} \cdot \frac{\partial C(x)}{\partial x}
$$

where $J\left(\mathrm{~mol} \mathrm{~cm}^{-2} \mathrm{~s}^{-1}\right)$ is the flux, $\varphi$ is the porosity of the substrate, $D_{\mathrm{s}}\left(\mathrm{cm}^{2} \mathrm{~s}^{-1}\right)$ is the diffusion coefficient, and $\partial C / \partial x\left(\mathrm{~mol} \mathrm{~cm}^{-4}\right)$ is the inclination of the concentration profile. The flux of $\mathrm{NO}_{\mathrm{x}}{ }^{-}$at a certain depth $(x)$ is thus calculated from the first derivative of the concentration profile.

Production or consumption of $\mathrm{NO}_{\mathrm{x}}^{-}$will result in a change in flux with depth, and activity profiles showing $\mathrm{NO}_{\mathrm{x}}{ }^{-}$production rates were therefore calculated from the first derivative of the flux profile, which corresponds to the second derivative of the concentration profile.

The concentration profiles were analysed mathematically by means of a discrete version of Fick's first law:

$$
J_{\left(x+1 / 2^{\Delta x}\right)}=D_{\mathrm{e}(x+1 / 2 \Delta x)} \cdot \frac{\left[C_{(x+\Delta x)}\right]-C(x)}{\Delta x}
$$

where $J_{(x+1 / 2 x)}$ is the flux at the depth between 2 data points, $D_{\mathrm{e}(x+1 / 2 \Delta x)}$ is the effective diffusion coefficient $\left(=\varphi \cdot D_{\mathrm{s}}\right)$ at the same depth, $C$ is the concentration and $\Delta x$ is the distance between the 2 data points. A flux profile was derived from the concentration profile by use of this equation. The flux profile was then used to calculate the activity profile by determining the first derivative:

$$
P_{(x)}=\frac{\left[J_{(x-1 / 2 \Delta x)}-J_{(x+1 / 2 \Delta x)}\right]}{2 \Delta x}
$$

where $P_{(x)}$ is the production (mol cm ${ }^{-3} \mathrm{~s}^{-1}$ ) at depth $x_{\text {, }}$ $J_{(x+1 / 2 \Delta x)}$ and $J_{(x-1 / 2 \Delta x)}$ are the fluxes $1 / 2 \Delta x$ above and below depth $x$, and $\Delta x$ is the distance between the data points. This calculation uses a total of 3 data points on the concentration profile for calculation of the activity $\left(C_{(x),} C_{(x+\Delta x)}\right.$, and $\left.C_{(x-\Delta x)}\right)$. Hence, the activity is calculated as the average change in flux over 2 depth intervals $(2 \Delta x)$.

Differentiation of the raw data in a concentration profile will often lead to a very noisy activity profile due to small variations in the data points. To increase the signal-to-noise ratio, we used an increasing number of data points (i.e. consecutive readings at equally spaced depths) to calculate the depth-specific activity. Most activity profiles were based on 7 data points (i.e. 3 readings above and 3 readings below the depth for which the activity was calculated). This resulted in smoothening of the activity profile, as the depthspecific activity was calculated as the average change in flux over the distance from $3 \Delta x$ above and below 
depth $x$. The formula for activity calculation based on 7 data points therefore is as follows:

$$
\begin{aligned}
& P_{(x)}= \\
& \frac{\left[J_{(x-21 / 2 \Delta x)}+J_{(x-11 / 2 \Delta x)}+J_{(x-1 / 2 \Delta x)}-J_{(x+1 / 2 \Delta x)}-J_{(x+11 / 2 \Delta x)}-J_{(x+21 / 2 \Delta x)}\right]}{6 \Delta x}
\end{aligned}
$$

With a $\Delta x$ of $0.2 \mathrm{~mm}$, the activity calculation based on 7 data points will use data within a range of $1.2 \mathrm{~mm}$. The spatial resolution was therefore reduced to $0.6 \mathrm{~mm}$ by averaging the activity of the depth intervals 3 by 3 . That is, the activity at the depth $0.4 \mathrm{~mm}$ is the average of the activity calculated at the following depths: 0.2 , 0.4 , and $0.6 \mathrm{~mm}$.

The individual activity profiles from a station were used to calculate an average activity profile, and the standard deviation could thus be calculated for the activity in each depth interval. It is thereby possible to determine whether the variation in the distribution of nitrification and $\mathrm{NO}_{\mathrm{x}}{ }^{-}$consumption activity is significant. This was performed at the stations where at least 3 concentration profiles were obtained (Stn 6 during illumination and Stns 3,4, and 5 in darkness). Activity profiles from these stations are therefore shown with error bars (see Fig. 4). Analysing several profiles together gives a better opportunity to evaluate the significance of the variation in activity with depth as compared to an individual profile interpretation (Berg et al. 1998).

The total $\mathrm{NO}_{\mathrm{x}}{ }^{-}$production and consumption rates per $\mathrm{cm}^{2}$ at Stns 2 to 6 were calculated by integration of the activity profile.

It turned out to be impossible to obtain $\mathrm{NO}_{\mathrm{x}}{ }^{-}$profiles at Stn 1 below a depth of $1.5 \mathrm{~mm}$ because of physical disturbance of the sediment. This was caused both by the presence of animal (polychaete) burrows and by pieces of partly degraded plant structures that were impenetrable by the sensors. However, the profiles seemed free of disturbance down to a depth of about $1.5 \mathrm{~mm}$, which the absence of noise on the oxygen profiles confirmed. The concentration profiles in this part of the sediment were linear, indicating no significant nitrification. The total $\mathrm{NO}_{\mathrm{x}}{ }^{-}$consumption per $\mathrm{m}^{2}$ could therefore be determined as the diffusive transport of $\mathrm{NO}_{\mathrm{x}}{ }^{-}$into the sediment. We calculated this flux using Fick's first law of diffusion (Eq. 1), where $\partial C / \partial x$ was determined as the inclination of the concentration profile in the linear part of the profile at 0 to $1 \mathrm{~mm}$ depth.

Measurement of $\boldsymbol{D}_{\mathrm{e}}$. A profile of the effective diffusion coefficient, $D_{\mathrm{e}}\left(=\varphi \cdot D_{\mathrm{s}}\right)$, was measured in a single core from each station. To determine $D_{\mathrm{e}}$ in the sediment with high spatial resolution, we measured a He profile in a He saturated core with a highly stirring sensitive He sensor (tip diameter $=100 \mu \mathrm{m}$ ). The signal of a stirring sensitive sensor at a given He concentra- tion is dependant on the rate of transport of He to the tip of the sensor, i.e. the degree of stirring. In a stagnant solution (the sediment), the variation in the signal of such a sensor at a constant He concentration is proportional to the variation in the diffusion coefficient.

The He sensor was constructed from a tapered glass pipette with a silicone membrane in the $100 \mu \mathrm{m}$ wide tip. The glass pipette was connected to a He-detecting mass spectrometer (leak detector, UL 200, Leybold, Cologne), and He diffusing through the silicone membrane was conducted through vacuum to the spectrometer. The concentration of $\mathrm{He}$ was constant throughout the sediment, but the flux of He into the sensor (and hence the signal of the spectrometer) depended on the diffusive properties of the sediment as the diffusive resistance in the silicone membrane was very small. For calibration of the sensor we recorded the signal of the spectrometer for measurement in glass beads and $1.5 \%$ agar, and compared these signals with determination of $D_{\mathrm{e}}$ in the same substances by the oxygen gradient method (Revsbech 1989b). It was assumed that the $D_{\mathrm{e}}$ ratio for $\mathrm{O}_{2} / \mathrm{He} / \mathrm{NO}_{3}{ }^{-}$did not vary in the different substrates.

For calculation of $\mathrm{NO}_{\mathrm{x}}{ }^{-}$consumption and production rates, the diffusion coefficient for nitrate was used, as HPLC measurements of nitrate plus nitrite showed that nitrate contributed most to the $\mathrm{NO}_{\mathrm{x}}{ }^{-}$pool. The diffusion coefficient for nitrate in water $\left(1.41 \times 10^{-5} \mathrm{~cm}^{2} \mathrm{~s}^{-1}\right)$ at the average salinity and temperature was estimated as described in Li \& Gregory (1974) and for $\mathrm{O}_{2}(1.80 \times$ $10^{-5} \mathrm{~cm}^{2} \mathrm{~s}^{-1}$ ) as described in Broecker \& Peng (1974).

Comparison of microsensor flux measurements to whole core flux measurements. The sediment oxygen consumption rates calculated from microsensor profiles by use of Fick's first law (Eq. 1) were compared to the measurement of oxygen consumption based on whole cores to evaluate the effect of bioturbation on the solute exchange between sediment and water.

Three cores from each station with an overlying water phase were sealed with airtight rubber stoppers and incubated in the dark for $3 \mathrm{~h}$. The water above the sediment was stirred with small magnetic bars attached to the rubber stopper. The height of the water column was noted, and the sediment oxygen consumption rate could then be calculated from measurements of the oxygen concentration in the water phase at the beginning and at the end of the incubation period. The oxygen concentration in the water above the sediment changed from $100 \%$ to not less than $50 \%$ of atmospheric saturation during the $3 \mathrm{~h}$ of incubation, hence the sediment did not suffer from oxygen depletion during the experiment. The nitrate concentration in the water phase during the whole core incubation was identical to the concentration during microsensor measurements. 
Estimation of $\boldsymbol{D}_{\mathrm{w}}$ and $\boldsymbol{D}_{\mathrm{n}}$. The measured concentration profiles were used to determine to what extent the $\mathrm{NO}_{\mathrm{x}}^{-}$flux from the water contributed to the calculated activity of $\mathrm{NO}_{\mathrm{x}}{ }^{-}$consumption. That is, how much of the total $\mathrm{NO}_{\mathrm{x}}^{-}$consumption rate $\left(D_{\mathrm{tot}}\right)$ was sustained by $\mathrm{NO}_{\mathrm{x}}^{-}$from the water $\left(D_{\mathrm{w}}\right)$, and how much was sustained from $\mathrm{NO}_{\mathrm{x}}{ }^{-}$originating from nitrification $\left(D_{\mathrm{n}}\right)$.

$D_{\mathrm{w}}$ was estimated by calculating the $\mathrm{NO}_{\mathrm{x}}{ }^{-}$concentration in the overlying water required to sustain the observed rate of $\mathrm{NO}_{\mathrm{x}}{ }^{-}$consumption if nitrification was zero. The ratio of the actual nitrate concentration to the estimated concentration corresponds to the ratio of $D_{\mathrm{w}} / D_{\text {tot }} . D_{\text {tot }}$ is the total depth-integrated $\mathrm{NO}_{\mathrm{x}}{ }^{-}$consumption rate, and $D_{\mathrm{w}}$ and $D_{\mathrm{n}}$ can be calculated from:

$$
\begin{aligned}
& D_{\mathrm{w}}=D_{\text {tot }} \cdot \frac{D_{\mathrm{w}}}{D_{\mathrm{tot}}} \\
& D_{\mathrm{n}}=D_{\text {tot }}-D_{\mathrm{w}}
\end{aligned}
$$

The principle of determining the theoretical water phase $\mathrm{NO}_{\mathrm{x}}{ }^{-}$concentration required to sustain the $\mathrm{NO}_{\mathrm{x}}{ }^{-}$ consumption in the sediment is a linear extrapolation of the concentration profile from the uppermost zone of $\mathrm{NO}_{\mathrm{x}}{ }^{-}$consumption to the surface of the diffusive boundary layer (Fig. 2). A linear concentration profile reflects a constant flux and thus no production of $\mathrm{NO}_{\mathrm{x}}^{-}$.

A simple linear extrapolation of the concentration profile would, however, not account for a change with depth of $D_{\mathrm{e}}$. Therefore, the theoretical concentration profile was calculated from the activity $\left(\mathrm{NO}_{\mathrm{x}}{ }^{-}\right.$consumption/production) profile, where $\mathrm{NO}_{\mathrm{x}}^{-}$production was set to zero. The procedure for this calculation is as follows:

A flux profile was calculated from the activity profile, after which the concentration profile was calculated from the flux profile. The flux at a certain depth, $x$, was calculated from:

$$
J_{(x)}=J_{(x+\Delta x)}-P_{(x)} \cdot \partial x
$$

where $J_{(x)}$ is the flux $\left(\mathrm{nmol} \mathrm{cm}^{-2} \mathrm{~s}^{-1}\right)$ at $x_{1} \partial x$ is the depth interval $(\mathrm{cm})$, and $P_{(\mathrm{x})}\left(\mathrm{nmol} \mathrm{cm} \mathrm{cm}^{-3} \mathrm{~s}^{-1}\right)$ is the $\mathrm{NO}_{\mathrm{x}}^{-}$ production rate at $x_{i}$ hence $\mathrm{NO}_{\mathrm{x}}{ }^{-}$consumption provides a negative value of $P_{(x)}$.

From the flux profile, the $\mathrm{NO}_{\mathrm{x}}^{-}$concentration at depth $x$ was calculated by:

$$
C_{(x)}=C_{(x+\Delta x)}+J_{(x)} \cdot \partial x \cdot D_{e(x)}
$$

Fig. 2 shows a measured $\mathrm{NO}_{\mathrm{x}}{ }^{-}$profile from $\mathrm{Stn} 5$; the corresponding activity profile, where nitrification rates are set to zero; and the $\mathrm{NO}_{\mathrm{x}}^{-}$concentration profile calculated from the activity profile. This calculation was only performed for Stns 2 to 5 as no nitrification could be detected at Stns 1 and 6 .

To evaluate the sediment as a source or sink for $\mathrm{NO}_{\mathrm{x}}{ }^{-}$, net fluxes of $\mathrm{NO}_{\mathrm{x}}{ }^{-}$across the sediment surface

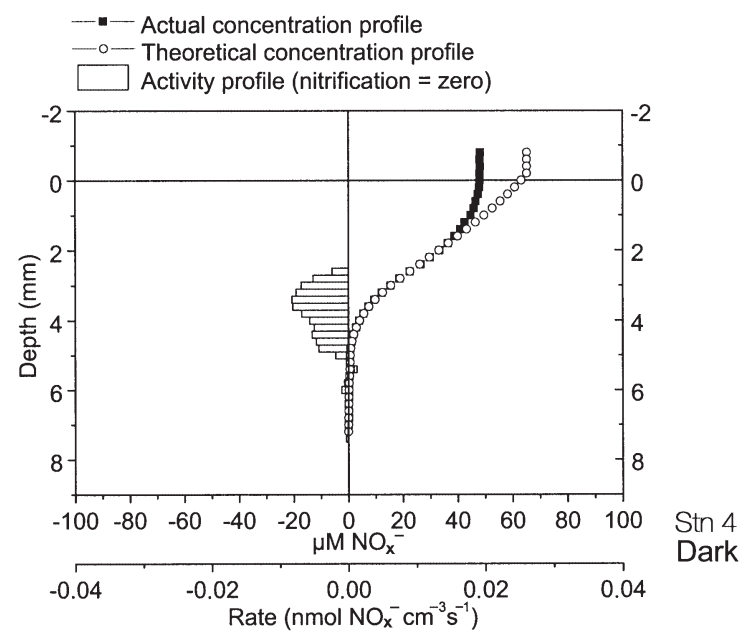

Fig. 2. Demonstration of an estimation of $D_{\mathrm{w}}$ by extrapolation of the $\mathrm{NO}_{\mathrm{x}}{ }^{-}$concentration profile (Stn 4, dark). The actual concentration profile, the theoretical concentration profile, and the activity profile used for calculation of the theoretical concentration profile are shown

were calculated from the concentration profiles. The flux was calculated by subtracting the integrated $\mathrm{NO}_{\mathrm{x}}{ }^{-}$ production rate from the consumption rate at Stns 2 to 6 , and from the concentration gradient across the sediment surface at Stn 1 . The gradient was measured just below the sediment surface.

\section{RESULTS}

The in situ conditions measured at each station are summarised in Table 1. The oxygen concentration at the sediment surface was close to air saturation at all stations. The temperature was $14.5^{\circ} \mathrm{C}$ at Stn 6 and $15.5^{\circ} \mathrm{C}$ at all other stations.

\section{Measurement of $D_{\mathrm{e}}$}

In the top $2 \mathrm{~mm}, D_{\mathrm{e}}$ decreased approximately exponentially, and below this there was a small linear decrease. The measured profiles of $D_{\mathrm{e}}$ were fitted to an exponential plus linear function (Fig. 3), which was used for the activity calculations. This was necessary as any abrupt change in $D_{\mathrm{e}}$ would result in noise on the activity profile.

\section{Distribution of oxygen and $\mathrm{NO}_{\mathrm{x}}^{-}$in the sediment}

Fig. 4 shows a typical set of $\mathrm{NO}_{\mathrm{x}}^{-}$and $\mathrm{O}_{2}$ profiles from each station during illumination (Fig. 4A-D) and in darkness (Fig. 4E-J). There was some variation 
Table 1. Water depth, $\mathrm{NO}_{\mathrm{x}}^{-}$concentration in the bottom water, light intensity at the sediment surface, and bottom water salinity at the different stations.

\begin{tabular}{|ccccc|}
\hline Stn & $\begin{array}{c}\text { Depth } \\
(\mathrm{m})\end{array}$ & $\begin{array}{c}\text { In situ light (\% of } \\
\text { surface intensity) }\end{array}$ & $\begin{array}{c}\text { Nitrate+nitrite } \\
(\mu \mathrm{M})\end{array}$ & $\begin{array}{c}\text { Salinity } \\
(\%)\end{array}$ \\
\hline 1 & 0.6 & 16 & 250 & 1 \\
2 & 0.3 & 64 & 55 & 9.9 \\
3 & 0.6 & 40 & 55 & 9.9 \\
4 & 1.2 & 17 & 55 & 9.9 \\
5 & 2.4 & 4 & 55 & 9.9 \\
6 & 0.6 & 71 & 5 & 20 \\
\hline
\end{tabular}

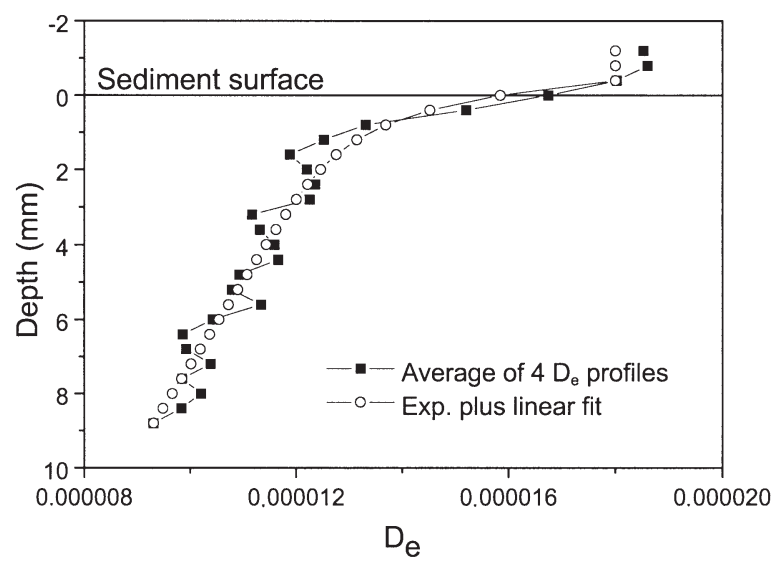

Fig. 3. Example of a diffusion coefficient, $D_{\mathrm{e}}$, profile and the linear plus exponential fit to this profile

between $\mathrm{NO}_{\mathrm{x}}{ }^{-}$profiles from the same station and the penetration of $\mathrm{NO}_{\mathrm{x}}{ }^{-}$into the sediment could differ by more than a millimetre between individual profiles from the same sediment core. Fig. 5 shows 3 different profiles from Stn 4 as an example of this variation. The stations that exhibited the most homogenous profiles were Stns 3, 5, and 6, where $\mathrm{NO}_{\mathrm{x}}^{-}$penetration depth only differed by less than $0.5 \mathrm{~mm}$ between individual profiles. Profiles from Stns 3, 5, and 6 were in general less noisy than profiles from other stations, and this reflects a homogenous sediment in terms of diffusive properties.

Oxygen generally penetrated down to about 2 to $3 \mathrm{~mm}$ depth in the dark (1 $\mathrm{mm}$ at Stn 6). Both in the dark and during illumination, $\mathrm{NO}_{\mathrm{x}}{ }^{-}$penetrated 2 to $4 \mathrm{~mm}$ deeper into the sediment than did oxygen at the medium salinity stations (Stns 2 to 5). Thus, $\mathrm{NO}_{\mathrm{x}}{ }^{-} \mathrm{Con}-$ sumption was occurring over a few millimetres below the depth of oxygen penetration, to a maximum depth of about $6 \mathrm{~mm}$. The concentration of $\mathrm{NO}_{\mathrm{x}}{ }^{-}$in the water phase at Stn 6 was very low, and all $\mathrm{NO}_{\mathrm{x}}{ }^{-}$diffusing into the sediment from the overlying water was depleted in
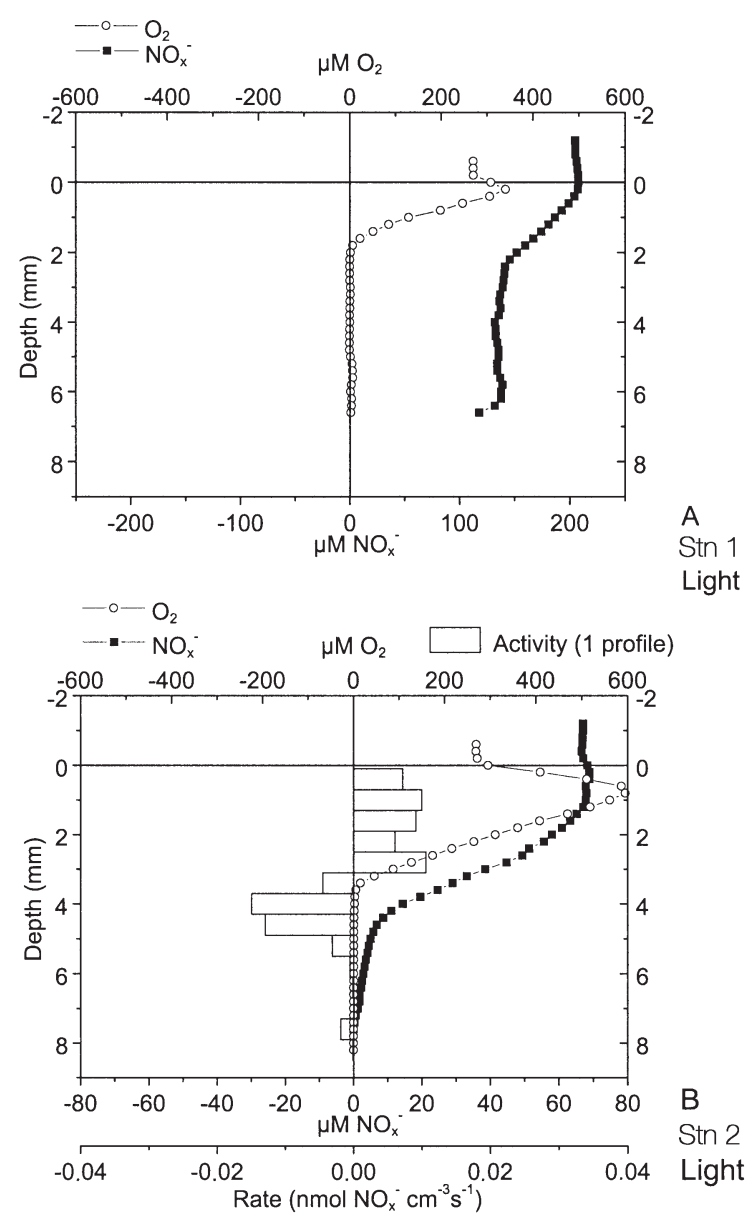

Fig. 4. (Above and next 2 pages.) (A-D) Light profiles from Stns 1-3 and 6. (E-J) Dark profiles from Stns 1-6. Oxygen and $\mathrm{NO}_{\mathrm{x}}{ }^{-}$concentration profiles and rates of $\mathrm{NO}_{\mathrm{x}}^{-}$production (positive values) and consumption (negative values) calculated from the concentration profile are shown. Activity profiles were calculated as the mean of several profiles. Error bars $=\mathrm{SD}$. No error bars are shown where the number of profiles used for activity calculation is less than 3

the upper oxic $1 \mathrm{~mm}$ of the sediment. At Stn 1, we were not able to determine how far $\mathrm{NO}_{\mathrm{x}}{ }^{-}$penetrated into the sediment because of physical disturbance of the profiles.

Benthic microphyte activity was observed at all stations where profiles were measured during illumination (Stns 1, 2, 3, and 6). The production of oxygen caused the oxic zone to penetrate 1 to $2 \mathrm{~mm}$ further into the sediment as compared to dark profiles at Stns 1, 2, and 6. At Stn 3, however, the light intensity was very low, and the small rate of oxygen production during illumination did not give rise to any significant change in oxygen penetration. It was not possible to detect any significant changes in $\mathrm{NO}_{\mathrm{x}}^{-}$penetration when comparing light and dark profiles from any of the stations. 

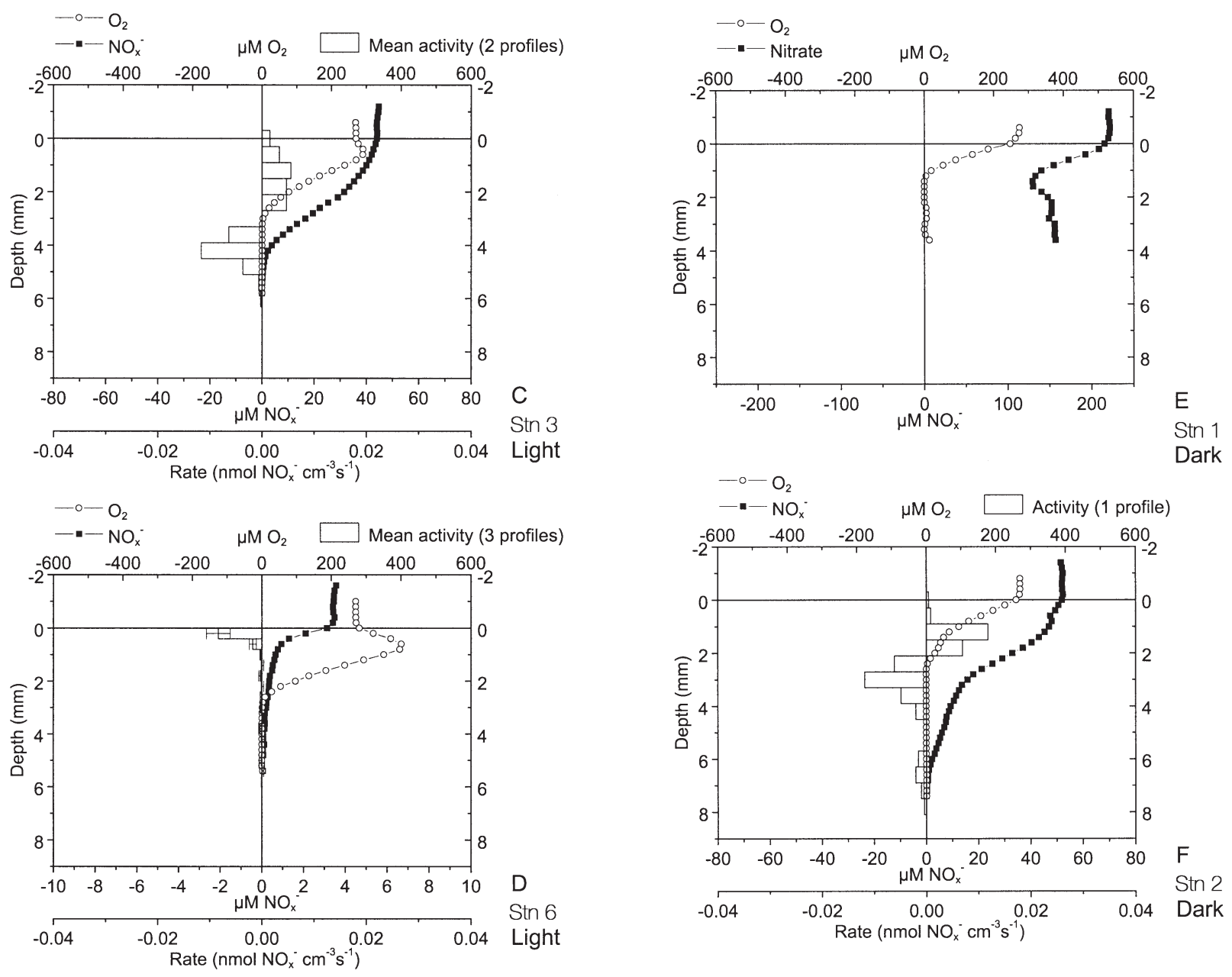

Fig. 4 (continued)

\section{Rates of $\mathrm{NO}_{\mathrm{x}}{ }^{-}$production and consumption}

The activity profiles shown in Fig. 4 are means of multiple profiles. For simplicity, positive rates indicate production and negative rates, consumption. $\mathrm{NO}_{\mathrm{x}}{ }^{-}$production was only observed at Stns 2 to 5 (medium salinity). Nitrification (measured as net $\mathrm{NO}_{\mathrm{x}}^{-}$production) calculated from the profiles from these stations was either highest close to the oxic/anoxic interface or evenly distributed throughout the oxic zone. $\mathrm{NO}_{\mathrm{x}}{ }^{-} \mathrm{con}-$ sumption rates in most profiles peaked about $2 \mathrm{~mm}$ below the nitrification maximum, and the width of the consumption zone varied between 2 and $4 \mathrm{~mm}$.

The total depth-integrated nitrification rate at Stns 2 to 5 varied between 37 and $75 \mu \mathrm{mol} \mathrm{N} \mathrm{m}{ }^{-2} \mathrm{~h}^{-1}$ (Table 2). In darkness, the variation between Stns 2 and 4 was not statistically significant $(t$-test, $\mathrm{p}<0.05)$ due to the large variation between individual profiles from each station. Only Stn 5 differed from the other stations by having a significantly lower nitrification rate. The effect of the shift between light and dark conditions could not be tested statistically because of too few replicates of measurements during illumination. At Stn 2 , the mean nitrification rates in darkness and during illumination were very similar. At Stn 3, however, the mean rate during illumination was only about twothirds of the rate in darkness.

To describe the influence of nitrification on the $\mathrm{NO}_{\mathrm{x}}^{-}$ consumption rates at Stns 2 to 5 , we estimated $D_{\mathrm{w}}$ and $D_{\mathrm{n}} . D_{\mathrm{n}}$ contributed $22,35,33$, and $15 \%$ of the total $\mathrm{NO}_{\mathrm{x}}^{-}$ consumption rate from dark measurements at Stns 2 to 5 , respectively. The corresponding results from light measurements at Stns 2 to 3 were 38 and 29\%. The average rates for each station are shown in Table 2 .

The total depth-integrated $\mathrm{NO}_{\mathrm{x}}{ }^{-}$consumption rate was calculated from each concentration profile at all stations. The mean value for each station is shown in Table 2. Comparison of dark profiles measured in cores sampled at equal depth along the salinity gradient (Stns 1, 3, and 6) shows a highly significant varia- 

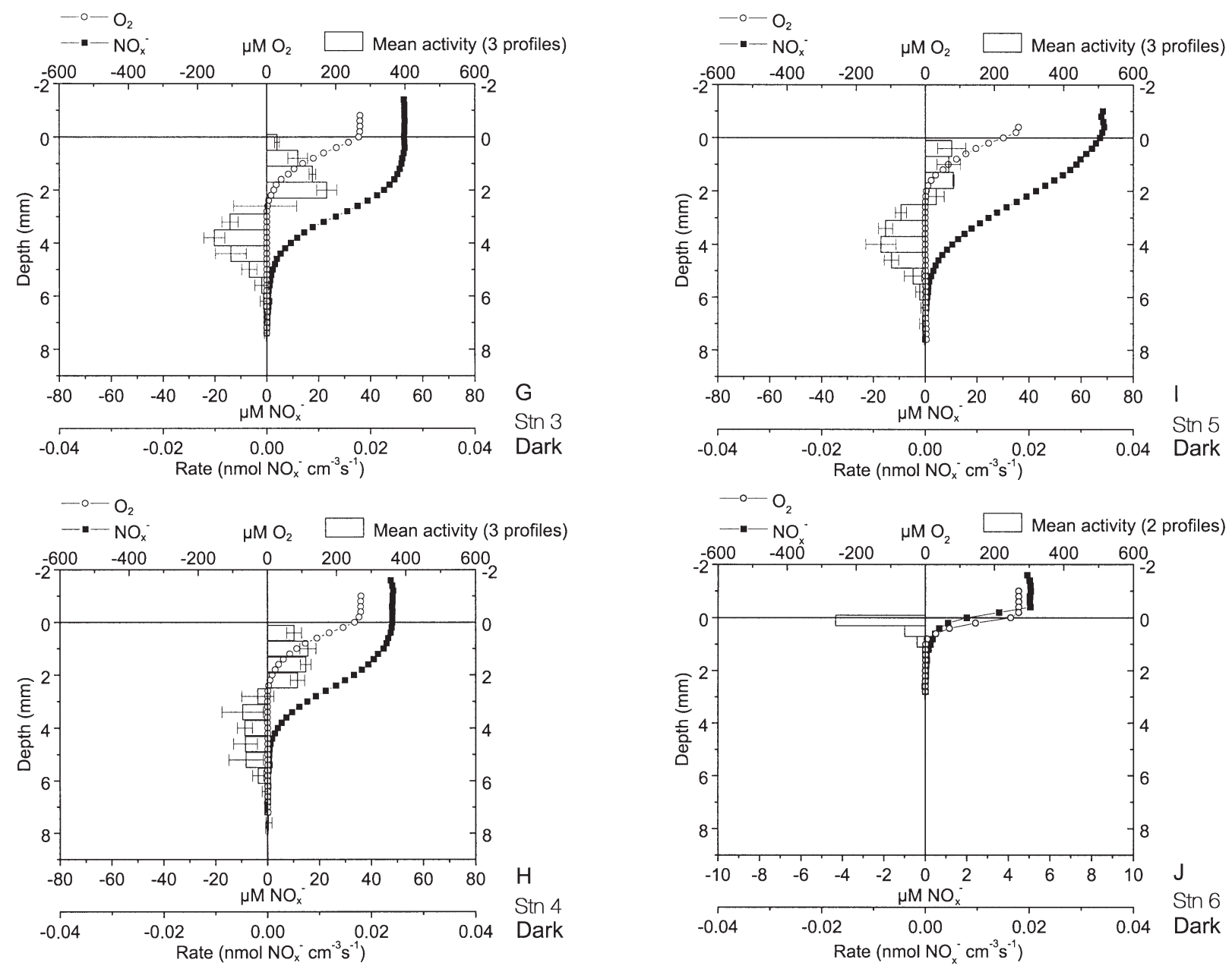

Fig. 4 (continued)

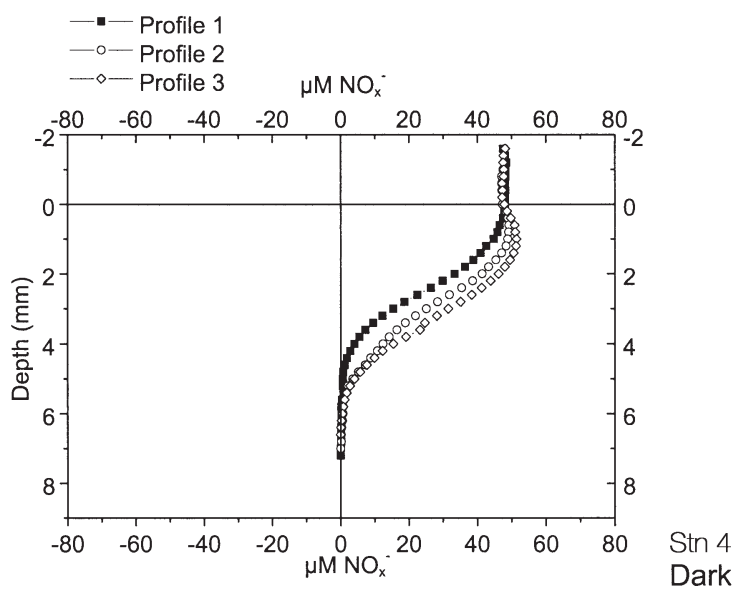

Fig. 5. Three nitrate profiles from Stn 4 (dark). All profiles were measured in the same sediment core

tion in the $\mathrm{NO}_{\mathrm{x}}{ }^{-}$consumption rate. The mean rate of $\mathrm{NO}_{\mathrm{x}}{ }^{-}$consumption per $\mathrm{m}^{2}$ increased with increasing $\mathrm{NO}_{\mathrm{x}}{ }^{-}$concentration and decreasing salinity.
Comparison of profiles measured in darkness to profiles measured at in situ light intensity shows that the mean rate of $\mathrm{NO}_{\mathrm{x}}{ }^{-}$consumption was higher in darkness than during illumination (Table 2). This difference is, however, only statistically significant at Stn 1. Unfortunately, heterogeneity in diffusivity at Stns 2 and 3 made it very difficult to obtain smooth concentration profiles with little noise. The low signal-tonoise ratio obscured activity calculations from most of these profiles, and only 2 profiles from each station were available for activity calculations. With only 2 replicates, it is not possible to state whether the difference in the means at Stns 2 and 3 is statistically significant.

Calculation of the $\mathrm{NO}_{\mathrm{x}}{ }^{-}$flux from the sediment into the water phase shows that the sediment did not play a significant role as a net sink for $\mathrm{NO}_{\mathrm{x}}{ }^{-}$where a significant rate of nitrification could be detected (Stns 2 to 5). The flux into the water phase of $\mathrm{NO}_{\mathrm{x}}{ }^{-}$produced by nitrification approximately balanced the flux of $\mathrm{NO}_{\mathrm{x}}^{-}$ from the water to the sediment. At Stn 4, there was 
Table 2. Mean rates $\left(\mu \mathrm{mol} \mathrm{m} \mathrm{m}^{-2} \mathrm{~h}^{-1}\right.$ ) of nitrification $\left(\mathrm{NO}_{\mathrm{x}}^{-}\right.$production) and $\mathrm{NO}_{\mathrm{x}}^{-}$ consumption ( $\mathrm{n}=$ number of replicates). $D_{\mathrm{w}}=\mathrm{NO}_{\mathrm{x}}{ }^{-}$consumption rate sustained by $\mathrm{NO}_{\mathrm{x}}^{-}$from the water phase. $D_{\mathrm{n}}=\mathrm{NO}_{\mathrm{x}}{ }^{-}$consumption rate sustained by $\mathrm{NO}_{\mathrm{x}}{ }^{-}$ produced in the sediment

\begin{tabular}{|lcccccccc|}
\hline Stn & $\begin{array}{c}\text { Nitrification } \\
\text { rate }\end{array}$ & SE & $\mathrm{n}$ & $\begin{array}{c}\text { Total } \mathrm{NO}_{\mathrm{x}}^{-} \\
\text {consumption rate }\end{array}$ & SE & $\mathrm{n}$ & $D_{\mathrm{w}}$ & $D_{\mathrm{n}}$ \\
\hline 1 light & 0 & & & 187 & 80 & 5 & 187 & 0 \\
2 light & 75 & - & 2 & 71 & - & 2 & 43 & 28 \\
3 light & 45 & - & 2 & 52 & - & 2 & 35 & 17 \\
6 light & 0 & & & 18 & 2.8 & 4 & 18 & 0 \\
1 dark & 0 & & & 429 & 103 & 5 & 429 & 0 \\
2 dark & 70 & - & 2 & 96 & - & 2 & 75 & 21 \\
3 dark & 66 & 4.3 & 3 & 69 & 1.1 & 3 & 45 & 24 \\
4 dark & 57 & 7.2 & 3 & 49 & 1.6 & 3 & 33 & 16 \\
5 dark & 37 & 2.5 & 3 & 69 & 2.7 & 3 & 58 & 11 \\
6 dark & 0 & & & 30 & 11.3 & 4 & 30 & 0 \\
\hline
\end{tabular}

from nitrification within the sediment. Therefore, the total rate of denitrification is affected by the position of the denitrification zone relative to the zone of nitrification and to the sediment surface (Nielsen et al. 1990). If denitrification is closely coupled to nitrification, it is indirectly affected by the factors controlling this, such as the supplies of ammonia and oxygen needed for this process (Jensen et al. 1993). The information we obtain from microsensor profiles about the exact position and size of $\mathrm{NO}_{\mathrm{x}}^{-}$production and consumption can therefore reveal how these processes are regulated under different conditions.

It is important to stress that by mea-

even a small flux of $\mathrm{NO}_{\mathrm{x}}{ }^{-}$out of the sediment. There was a small flux of $\mathrm{NO}_{\mathrm{x}}{ }^{-}$into the sediment at Stns 5 and 6 , but it did not exceed $30 \mu \mathrm{mol} \mathrm{N} \mathrm{m} \mathrm{N}^{-2} \mathrm{~h}^{-1}$. Only in the innermost part of the fjord (Stn 1) was there a substantial flux of $\mathrm{NO}_{\mathrm{x}}{ }^{-}$from the water to the sediment (up to $577 \mu \mathrm{mol} \mathrm{N} \mathrm{m}^{-2} \mathrm{~h}^{-1}$ ).

\section{Comparison of microsensor flux measurements to whole core flux measurements}

The rates of oxygen consumption determined by whole core incubation were a factor of 1.5 to 4.5 times higher than the corresponding oxygen fluxes calculated from microsensor profiles (Table 3). The largest difference was found at Stns 2 to 5 .

\section{DISCUSSION}

The rate of denitrification is mainly regulated by temperature, the oxygen level, and the availability of nitrate and organic carbon (Seitzinger 1988). Nitrate can originate from the water above the sediment or suring only production and consumption of $\mathrm{NO}_{\mathrm{x}}{ }^{-}$we were not able to distinguish denitrification from dissimilative reduction of nitrate to ammonia, assimilation of nitrate, or other $\mathrm{NO}_{\mathrm{x}}{ }^{-}$consuming processes in the present study. It should also be noted that the calculated rates of $\mathrm{NO}_{\mathrm{x}}^{-}$production and consumption are net rates. They should therefore be considered minimum rates, as any overlap of production and consumption zones would result in underestimation of the actual rates.

Taking the variation in $D_{\mathrm{e}}$ with depth into account made it possible to calculate activity rates with higher accuracy compared to an approach where a constant diffusion coefficient throughout the core was assumed. Similar data may be obtained by an electrochemical diffusivity sensor (Revsbech et al. 1998). The present method, however, has the advantage that a small membrane inlet sensor is easy to construct and quadropole mass spectrometers are available in many laboratories. Furthermore, He is not metabolised in the sediment, and measurements can therefore be performed without inhibition of metabolic activity.

It is important to stress that, even though this method gives a better resolution of the change in $D_{\mathrm{e}}$ down

Table 3. Mean rates $\left(\mu \mathrm{mol} \mathrm{m} \mathrm{m}^{-2} \mathrm{~h}^{-1}\right.$ ) of oxygen uptake based on whole core measurements and surface fluxes (microsensor measurements)

\begin{tabular}{|lccccc|}
\hline Stn & $\begin{array}{c}\text { Whole-core } \mathrm{O}_{2} \text { consumption } \\
\text { (mean of 3-4 columns) }\end{array}$ & SE & $\begin{array}{c}\text { Sediment surface oxygen flux } \\
\text { (mean of 3-5 profiles) }\end{array}$ & $\begin{array}{c}\text { SE } \\
\text { Whole core flux/ } \\
\text { surface flux }\end{array}$ \\
\hline 1 & 2960 & 493 & 1765 & 444 & 1.7 \\
2 & 4834 & 144 & 1387 & 399 & 175 \\
3 & 4363 & 918 & 967 & 450 & 4.5 \\
4 & 2914 & 616 & 730 & 67 & 4.0 \\
5 & 2276 & 329 & 2018 & 786 & 1.8 \\
6 & 3034 & 158 & & & 1.5 \\
\hline
\end{tabular}


through the sediment, it cannot account for local heterogeneity caused by, for example, fauna burrows or small pebbles, as such heterogeneity would be very variable between individual cores.

We observed $\mathrm{NO}_{\mathrm{x}}{ }^{-}$to penetrate up to $7 \mathrm{~mm}$ into the sediment, whereas oxygen only penetrated down to 2-4 $\mathrm{mm}$. The extent of oxygen penetration into the sediment has been shown to affect both production and consumption of nitrate (Nielsen et al. 1990, Jensen et al. 1994, Rysgaard et al. 1994). If oxygen is limiting nitrification, increased oxygen penetration will stimulate nitrification. The effect on nitrate consumption can be either positive or negative. If nitrate consumption is closely coupled to nitrification, it will be stimulated by the increased nitrate production (Jensen et al. 1994, Lorenzen et al. 1998). If not, consumption may decrease as the increased oxygen penetration pushes the anoxic nitrate reduction zone further into the sediment and increases the diffusion path of nitrate from the water phase to the consumption zone (Nielsen et al. 1990, Lorenzen et al. 1998).

We observed an increase in oxygen penetration of 0 to $2 \mathrm{~mm}$ under in situ light conditions as compared to profiles measured in darkness at Stns 1, 2, 3, and 6. In a study of freshwater sediment, Lorenzen et al. (1998) found that the depth-integrated nitrification rate increased from zero to $360 \mu \mathrm{mol} \mathrm{N} \mathrm{m} \mathrm{N}^{-2} \mathrm{~h}^{-1}$ when the $\mathrm{O}_{2}$ penetration increased by $1.3 \mathrm{~mm}$ during illumination. In our study, however, the nitrification rate (Stns 2 and 3) did not increase during illumination as compared to darkness. Nitrification thus did not seem to be limited by the availability of oxygen.

The increased oxygen penetration during illumination caused a reduction in the flux of $\mathrm{NO}_{\mathrm{x}}{ }^{-}$into the sediment at Stn 1 to less than $50 \%$ of the rate in darkness. This would be expected in such a sediment where virtually all $\mathrm{NO}_{\mathrm{x}}{ }^{-}$consumed originated from the overlying water and therefore was highly dependent on the distance from the anoxic zone to the sediment surface. It was not possible to measure the depth of $\mathrm{NO}_{\mathrm{x}}{ }^{-}$penetration at this station. However, by extrapolating the linear part of the concentration profiles downwards, one can estimate the average depth of $\mathrm{NO}_{\mathrm{x}}{ }^{-}$depletion. When shifting from dark to light conditions, this estimated depth changed from 2-3 to $3-6 \mathrm{~mm}$ (data not shown).

The reduction in the $\mathrm{NO}_{\mathrm{x}}{ }^{-}$consumption rate at Stns 2 and 3 was much smaller than observed at Stn 1, and unfortunately, the difference could not be tested statistically due to the lack of replicates.

A decrease in the mean rate of $\mathrm{NO}_{\mathrm{x}}{ }^{-}$consumption was also observed at Stn 6, but it was not statistically significant. The variation observed is most likely to be due to variations in the water phase concentration, which varied between 3.5 and $5 \mu \mathrm{M}$ during the exper- iment. There was no net production of $\mathrm{NO}_{\mathrm{x}}^{-}$at this station, and depletion of $\mathrm{NO}_{\mathrm{x}}{ }^{-}$in the oxic zone indicates that $\mathrm{NO}_{\mathrm{x}}{ }^{-}$was assimilated rather than used in anaerobic respiration.

We can conclude that a change in light conditions within the in situ range (80 to $200 \mu \mathrm{E}$ ) of light intensity only affected the transformation of $\mathrm{NO}_{\mathrm{x}}{ }^{-}$significantly where the $\mathrm{NO}_{\mathrm{x}}{ }^{-}$concentration was very high and $\mathrm{NO}_{\mathrm{x}}{ }^{-}$ consumption almost entirely depended on $\mathrm{NO}_{\mathrm{x}}{ }^{-}$diffusing from the overlying water. There may be several reasons why we did not observe a significant effect of light at the stations with intermediate salinity and $\mathrm{NO}_{\mathrm{x}}^{-}$ concentrations. First, calculated activities of $\mathrm{NO}_{\mathrm{x}}{ }^{-}$production and consumption are net rates. An increased $\mathrm{NO}_{\mathrm{x}}{ }^{-}$production by nitrification may be balanced by increased assimilation of $\mathrm{NO}_{\mathrm{x}}{ }^{-}$by the benthic microalgae as their metabolic activity increases when exposed to light (Rysgaard et al. 1993). Likewise, where nitrification and denitrification overlap an increase in both rates might not affect the concentration profile. Such an overlap has been suggested by Blackburn et al. (1994) in a study of a freshwater sediment where intensity and distribution of nitrification and denitrification was simulated by a computer model to match the measured activities and $\mathrm{NO}_{\mathrm{x}}{ }^{-}$profiles. Furthermore, the increased oxygen penetration caused by illumination was rather modest, and the relatively high variability in the calculated $\mathrm{NO}_{\mathrm{x}}{ }^{-}$consumption rates (and the few replicates) may have obscured the response pattern.

The rate of $\mathrm{NO}_{\mathrm{x}}{ }^{-}$consumption was strongly dependent on the concentration of $\mathrm{NO}_{\mathrm{x}}{ }^{-}$in the water, and a large part of the $\mathrm{NO}_{\mathrm{x}}{ }^{-}$consumed thus originated from the water and not from nitrification. This is consistent with what has been found in many studies of denitrification in systems with nitrate concentrations in the range of 20 to $200 \mu \mathrm{M}$ (Christensen et al. 1990, Nielsen et al. 1990, Ogilvie et al. 1997, Pind et al. 1997). A tight coupling between nitrification and nitrate consumption is usually found in systems with low nitrate concentrations $(<10 \mu \mathrm{M})$ (Nishio et al. 1983, Jenkins \& Kemp 1984, Stockenberg \& Johnstone 1997).

We estimated a $D_{\mathrm{n}}$ of zero at Stn 1 . It is possible that nitrification was present, but the rate was below the detection limit of this method. The flux of $\mathrm{NO}_{\mathrm{x}}{ }^{-}$into the sediment at Stn 1 was very large compared to the other stations. On such a large background $\mathrm{NO}_{\mathrm{x}}^{-}$flux, it would take a relatively large production rate (change in flux) to affect the concentration profile to an extent that can be distinguished from the general noise of the data points. If nitrification was present at Stn 1, the rate would be much smaller than the $\mathrm{NO}_{\mathrm{x}}{ }^{-}$flux into the sediment, thus $D_{\mathrm{n}}$ would be very small compared to $D_{\mathrm{w}}$.

$D_{\mathrm{n}}$ was calculated to be 15 to $35 \%$ of $D_{\text {tot }}$ at Stns 2 to 5 (dark profiles). This indicates a coupling between 
$\mathrm{NO}_{\mathrm{x}}{ }^{-}$production and consumption in this part of Randers Fjord; however, the coupling is not very close. $D_{\mathrm{n}}$ only accounted for about one-third of the $\mathrm{NO}_{\mathrm{x}}^{-}$produced by nitrification, which indicates that most of this $\mathrm{NO}_{\mathrm{x}}{ }^{-}$diffused out of the sediment instead of being consumed by denitrification and other $\mathrm{NO}_{\mathrm{x}}^{-}$-consuming processes in the sediment.

Sømod et al. (1999) measured denitrification in Randers Fjord in June 1995 by the ${ }^{15} \mathrm{~N}$ isotope pairing technique. They found total denitrification rates of about $260 \mu \mathrm{mol} \mathrm{N} \mathrm{m} \mathrm{N}^{-2} \mathrm{~h}^{-1}$ at 2 stations comparable to our Stns 1 and 3. There was no correlation between denitrification and the water-phase concentration of nitrate in their study, and $D_{\mathrm{n}}$ contributed to more than half of the total denitrification. The difference between this and the present study may illustrate the large temporal variability in nitrification and $\mathrm{NO}_{\mathrm{x}}{ }^{-}$consumption, but at least part of the discrepancy may also be due to bioturbation (see below).

The rates of total $\mathrm{NO}_{\mathrm{x}}{ }^{-}$consumption measured in this study are within the range of denitrification rates found in similar systems (Jørgensen \& Sørensen 1988, Yoon \& Benner 1992, Nowicki 1994, Nielsen et al. 1995, Cabrita \& Brotas 2000). In a review of denitrification studies in freshwater and coastal marine environments, reported rates from estuarine environments in temperate regions of the Northern Hemisphere are within a range of 50 to $250 \mu \mathrm{mol} \mathrm{N} \mathrm{m}{ }^{-2} \mathrm{~h}^{-1}$ (Seitzinger 1988). All of these rates were based on bulk flux measurements. When calculating area-based $\mathrm{NO}_{\mathrm{x}}{ }^{-}$consumption rates from microsensor profiles, one might underestimate the actual rates. The high spatial resolution, which is a strength of the microsensor technique, becomes a drawback when calculating total area-based rates. Bioturbation by infauna, especially polychaetes and amphipods, can drastically affect the total area of the sediment/water interface and thereby increase the total $\mathrm{NO}_{\mathrm{x}}{ }^{-}$consumption rate of the sediment (Pelegri et al. 1994, Gilbert et al. 1995, 1998, Pelegri \& Blackburn 1995, Svensson \& Leonardson 1996, Bartoli et al. 2000). Pelegri et al. (1994) showed that the presence of 19800 individuals of Corophium volutator $\mathrm{m}^{-2}$ increased the oxygen uptake of the sediment by a factor of 2 . Uptake of nitrate by the sediment can increase even more than the oxygen uptake in the presence of infauna. If nitrate and oxygen are taken up only by simple diffusion over the sediment surface, model calculations and experimental data have shown that the ratio of nitrate uptake to nitrate concentration in the water is only about 1:3 of the ratio of oxygen uptake to oxygen concentration (Christensen et al. 1990). However, in burrows of infauna, nitrate and oxygen are transported through the burrow, which in the extreme situation may allow all of the nitrate and oxygen in the water to be consumed, and this would change the uptake:concentration ratio to 1:1. Hence, the uptake of nitrate for denitrification not only increases as a result of a larger surface area but also because of a more efficient uptake of nitrate in fauna burrows compared to the sediment surface. The observed increase in denitrification rates in the presence of infauna is generally twice as high as the increase in oxygen uptake (Binnerup et al. 1992, Pelegri et al. 1994, Pelegri \& Blackburn 1995, Svensson \& Leonardson 1996).

Nitrification, and thereby $D_{\mathrm{n}}$, is also stimulated by bioturbation. Nitrification is increased due to the creation of an additional sediment/water interface in a high- $\mathrm{NH}_{4}{ }^{+}$environment, and due to a stimulation of the growth of nitrifying bacteria by components in the lining of the burrow wall of polychaetes (Kristensen et al. 1985). Furthermore, nitrification and denitrification become more closely coupled as nitrate diffusing from the nitrification zone and into the water of a burrow may be transported to another section of the burrow and eventually be denitrified.

Polychaetes (Nereis sp.) and amphipods (Corophium sp.) were observed in our samples but the abundance was not quantified. We compared the oxygen flux across the sediment surface determined by microsensor profiles to the rate of oxygen consumption for whole cores to get a rough idea about the effect of bioturbation on the sediment-water solute fluxes. The oxygen consumption rates from whole core measurements were up to 4.5 times higher as compared to the microsensor measurements, and the whole core $\mathrm{NO}_{\mathrm{x}}{ }^{-}$ consumption rates must therefore also have been considerably higher than the rates determined from microsensor profiles.

For microsensor studies, the $\mathrm{NO}_{\mathrm{x}}{ }^{-}$biosensor used in this study has some obvious advantages over the existing LIX nitrate sensor and $\mathrm{N}_{2} \mathrm{O}$ sensors previously used for denitrification studies. As mentioned in the introduction, the $\mathrm{NO}_{\mathrm{x}}{ }^{-}$biosensor does not suffer from interference from other ions, which makes it possible to apply this sensor in marine environments where LIX sensors cannot be used. Nitrous oxide sensors are used to measure the production of $\mathrm{N}_{2} \mathrm{O}$ from denitrification following inhibition of nitrous oxide reductase by acetylene (Revsbech et al. 1988, Nielsen et al. 1990). This technique only allows for measurement of $D_{\mathrm{w}}$ as nitrification is also inhibited by acetylene (Hyman \& Wood 1985). This method is therefore disadvantageous where nitrification and denitrification are tightly coupled. A further complication by work with acetylene inhibition is that the inhibition of the $\mathrm{N}_{2} \mathrm{O}$ reductase may be incomplete (Kaspar 1982, Nielsen et al. 1990, Dalsgaard \& Bak 1992).

The only study of nitrification/denitrification in sediments performed previously with this biosensor for 
$\mathrm{NO}_{\mathrm{x}}{ }^{-}$is the study by Lorenzen et al. (1998), using sediment from a freshwater lake. The results presented here represent the first study of the microscale distribution of nitrate plus nitrite under various conditions in a marine environment. In contrast to the homogenous nitrate profiles found in freshwater sediment by Lorenzen et al. (1998), we found a great deal of patchiness in terms of diffusion properties, activities, and penetration depths of $\mathrm{NO}_{\mathrm{x}}^{-}$in the estuarine sediment. Physical disturbance or patchiness in general creates a variance that makes it difficult to calculate and compare areabased activity rates from different sites. This is especially the case for Stns 2 and 3 in our study. The advantage of microsensor measurements is thus to provide detailed information about the microscale distribution of nitrate/nitrite production and consumption to achieve an understanding of how these processes are controlled under different environmental conditions.

\section{LITERATURE CITED}

Andersen TK, Jensen MH, Sorensen J (1984) Diurnal variation of nitrogen cycling in coastal, marine sediments: 1. Denitrification. Mar Biol 83:171-176

Bartoli M, Nizzoli D, Welsh DT, Viaroli P (2000) Short-term influence of recolonisation by the polychaete worm Nereis succinea on oxygen and nitrogen fluxes and denitrification: a microcosm simulation. Hydrobiologia 431:165-174

Berg P, Risgaard-Petersen N, Rysgaard S (1998) Interpretation of measured concentration profiles in sediment pore water. Limnol Oceanogr 43:1500-1510

Binnerup SJ, Jensen K, Revsbech NP, Jensen MH, Sørensen J (1992) Denitrification, dissimilatory reduction of nitrate to ammonium, and nitrification in a bioturbated estuarine sediment as measured with $15 \mathrm{~N}$ and microsensor techniques. Appl Environ Microbiol 58:303-313

Blackburn HT, Blackburn ND, Jensen K, Risgaard-Petersen N (1994) Simulation model of the coupling between nitrification and denitrification in a freshwater sediment. Appl Environ Microbiol 60:3089-3095

Broecker WS, Peng TH (1974) Gas exchange between air and sea. Tellus 26:21-35

Cabrita MT, Brotas V (2000) Seasonal variation in denitrification and dissolved nitrogen fluxes in intertidal sediments of the Tagus estuary, Portugal. Mar Ecol Prog Ser 202: 51-65

Christensen PB, Nielsen LP, Sorensen J, Revsbech NP (1990) Denitrification in nitrate-rich streams: diurnal and seasonal variation related to benthic oxygen metabolism. Limnol Oceanogr 35:640-651

Crank J (1983) The mathematics of diffusion. Oxford University Press, London

Dalsgaard T, Bak F (1992) Effect of acetylene on nitrous oxide reduction and sulfide oxidation in batch and gradient cultures of Thiobacillus denitrificans. Appl Environ Microbiol 58:1601-1608

De Beer D, Sweerts JRA (1989) Measurement of nitrate gradients with an ion-selective microelectrode. Anal Chim Acta 219:351-356

García HE, Gordon LI (1992) Oxygen solubility in seawater: better fitting equations. Limnol Oceanogr 37:1307-1312

Gilbert F, Bonin P, Stora G (1995) Efect of bioturbation on denitrification in a marine sediment from the west Mediterranean littoral. Hydrobiologia 304:49-58

Gilbert F, Stora G, Bonin P (1998) Influence of bioturbation on denitrification activity in Mediterranean coastal sediments: an in situ experimental approach. Mar Ecol Prog Ser 163:99-107

Glud RN, Gundersen JK, Revsbech NP, Jørgensen BB (1994) Effects on the benthic diffusive boundary layer imposed by microelectrodes. Limnol Oceanogr 39(2):462-467

Herbert RA (1999) Nitrogen cycling in coastal marine ecosystems. FEMS Microbiol Rev 23:563-590

Hyman MR, Wood PM (1985) Suicidal inactivation and labeling of ammonia mono-oxygenase by acetylene. Biochem J 227:719-726

Jenkins MC, Kemp WM (1984) The coupling of nitrification and denitrification in two estuarine sediments. Limnol Oceanogr 29:609-619

Jensen K, Revsbech NP, Nielsen LP (1993) Microscale distribution of nitrification activity in sediment determined with a shielded microsensor for nitrate. Appl Environ Microbiol 59:3287-3296

Jensen K, Sloth NP, Risgaard Petersen N, Rysgaard S, Revsbech NP (1994) Estimation of nitrification and denitrification from microprofiles of oxygen and nitrate in model sediment systems. Appl Environ Microbiol 60:2094-2100

Jørgensen KS, Sørensen J (1988) Two annual maxima of nitrate reduction and denitrification in estuarine sediment (Norsminde Fjord, Denmark). Mar Ecol Prog Ser 48: 148-154

Kaspar HF (1982) Denitrification in marine sediment: measurement of capacity and estimate of in situ rate. Appl Environ Microbiol 43:522-527

Kjær T, Larsen LH, Revsbech NP (1999) Sensitivity control of ion-selective biosensors by electrophoretically mediated analyte transport. Anal Chim Acta 391:57-63

Kristensen E, Jensen MH, Andersen TK (1985) The impact of polychaete (Nereis virens Sars) burrows on nitrification and nitrate reduction in estuarine sediments. J Exp Mar Biol Ecol 85:75-91

Larsen LH, Kjær T, Revsbech NP (1997) A microscale $\mathrm{NO}_{3}{ }^{-}$ biosensor for environmental appications. Anal Chem 69: 3527-3531

Li YH, Gregory S (1974) Diffusion of ions in sea water and in deep-sea sediments. Geochim Cosmochim Acta 38: 703-714

Lorenzen J, Larsen L, Kjær T, Revsbech NP (1998) Biosensor determination of the microscale distribution of nitrate, nitrate assimilation, nitrification and denitrification in a diatom inhabited freshwater sediment. Appl Environ Microbiol 64:3264-3269

Messer J, Brezonik PL (1983) Comparison of denitrification rate estimation techniques in a large, shallow lake. Water Res 17:631-640

Nielsen K, Nielsen LP, Rasmussen P (1995) Estuarine nitrogen retention independently estimated by the denitrification rate and mass balance methods: a study of Norsminde Fjord, Denmark. Mar Ecol Prog Ser 119:275-283

Nielsen LP, Christensen PB, Revsbech NP, Sorensen J (1990) Denitrification and photosynthesis in stream sediment studied with microsensor and whole-core techniques. Limnol Oceanogr 35:1135-1144

Nishio T, Koike I, Hattori A (1983) Estimates of denitrification and nitrification in coastal and estuarine sediments. Appl Environ Microbiol 45:444-450

Nowicki BL (1994) The effect of temperature, oxygen, salinity, and nutrient enrichment on esturarine denitrification rates measured with a modified nitrogen gas flux technique. 
Estuar Coast Shelf Sci 38:137-156

Ogilvie B, Nedwell DB, Harrison RM, Robinson A, Sage A (1997) High nitrate, muddy estuaries as nitrogen sinks: the nitrogen budget of the River Colne estuary (United Kingdom). Mar Ecol Prog Ser 150:217-228

Pelegri SP, Blackburn TH (1995) Effect of bioturbation by Nereis sp., Mya arenaria and Cerastoderma sp. on nitrification and denitrification in estuarine sediments. Ophelia 42:289-299

Pelegri SP, Nielsen LP, Blackburn TH (1994) Denitrification in estuarine sediment stimulated by the irrigation activity of the amphipod Corophium volutator. Mar Ecol Prog Ser 105:285-290

Pind A, Risgaard Petersen N, Revsbech NP (1997) Denitrification and microphytobenthic $\mathrm{NO}_{3}{ }^{-}$consumption in a Danish lowland steam: diurnal and seasonal variation. Aquat Microb Ecol 12:275-284

Revsbech NP (1989a) An oxygen microsensor with a guard cathode. Limnol Oceanogr 34:474-478

Revsbech NP (1989b) Diffusion characteristics of microbial communities determined by use of oxygen microsensors. J Microbiol Methods 9:111-122

Revsbech NP, Nielsen LP, Christensen PB, Sorensen J (1988) Combined oxygen and nitrous oxide microsensor for denitrification studies. Appl Environ Microbiol 54:2245-2249

Revsbech NP, Nielsen LP, Ramsing NB (1998) A novel microsensor for determination of diffusivity in sediments and biofilms. Limnol Oceanogr 45:986-992

Risgaard-Petersen N, Rysgaard S, Nielsen LP, Revsbech NP (1994) Diurnal variation of denitrification and nitrification

Editorial responsibility: Bess Ward,

Princeton, New Jersey, USA in sediments colonized by benthic microphytes. Limnol Oceanogr 39:573-579

Rysgaard S, Risgaard-Petersen N, Nielsen LP, Revsbech NP (1993) Nitrification and denitrification in lake and estuarine sediments measured by the ${ }^{15} \mathrm{~N}$ dilution technique and isotope pairing. Appl Environ Microbiol 59: 2093-2098

Rysgaard S, Risgaard-Petersen N, Sloth NP, Jensen $K$, Nielsen LP (1994) Oxygen regulation of nitrification and denitrification in sediments. Limnol Oceanogr 39: 1643-1652

Seitzinger SP (1988) Denitrification in freshwater and coastal marine ecosystems: ecological and geochemical significance. Limnol Oceanogr 33:702-724

Sømod B, Larsen JE, Hansen DF, Düwel L, Andersen P (1999) Vandmiljøet i Randers Fjord 1997. Natur og Miljo, Århus Amt, Århus

Stockenberg A, Johnstone RW (1997) Benthic denitrification in the Gulf of Bothnia. Estuar Coastal Shelf Sci 45:835-843

Svensson JM, Leonardson L (1996) Effects of bioturbation by tube-dwelling chironomid larvae on oxygen uptake and denitrifcation in eutrophic lake sediments. Freshw Biol 35: 289-300

Verschuren PG, van der Baan JL, Blaauw R, de Beer D, van den Heuvel JC (1999) A nitrate-selective microelectrode based on a lipophilic derivative of iodocobalt(III)salen. Fresenius. J Anal Chem 364:595-598

Yoon WB, Benner R (1992) Denitrification and oxygen consumption in sediments of two south Texas estuaries. Mar Ecol Prog Ser 90:157-167

Submitted: January 10, 2001; Accepted: September 13, 2001 Proofs received from author(s): November 22, 2001 